\title{
Limited upper midline incision for major hepatectomy in adults: safety and feasibility
}

\author{
Ahmad Mahamid(D), Yaniv Fenig(D), Salvatore Amodeo(D), Lucas Facciuto(D), Dagny Vonahrens(D), Omri Sulimani(D), Thomas Schiano(D),
} Marcelo Facciuto(D)

Recanati/Miller Transplantation Institute, The Mount Sinai Hospital, New York, United States

\section{ABSTRACT}

Objective: Optimal incision for major hepatectomy remains controversial. In this study, we described our experience with a limited upper midline incision (UMI) for major hepatectomy. The objective was to analyze the feasibility and safety of UMI in major hepatectomy.

Material and Methods: Fifty-seven consecutive patients who underwent major hepatectomies performed via an UMI were compared to a control group of 36 patients who underwent major hepatectomies with a conventional incision (Cl).

Results: In $85 \%$ of the patients, the indication was malignancy, with a median tumor size of $6 \mathrm{~cm}$. Fifty-three percent of the patients had underlying chronic liver disease, and liver fibrosis was found in $61 \%$ of the patients. Ninteen percent of the patients had previous upper abdominal surgery. Twentysix patients underwent left hepatectomy, 20 patients had right hepatectomy and 11 patients trisegmentectomy. Additional combined surgical procedures were performed in $42 \%$ of the patients. Median operative time was 323 minutes, estimated blood loss was 500 ml, and median post-operative hospital stay was seven days. Surgical complications occurred in 22 patients (39\%). 5-year overall survival was $67 \%$. When compared with the control group with $\mathrm{Cl}$, patients with UMI had no statistical difference on operative time, estimated blood loss, length of hospital stay, complication rate, and overall survival.

Conclusion: Major hepatectomies can be safely performed through UMI. This approach should be considered as a reasonable option in addition to conventional and laparoscopic approaches for major hepatectomies.

Keywords: Upper midline incision, right hepatectomy, left hepatectomy, trisegmentectomy, major hepatectomy

Cite this article as: Mahamid A, Fenig Y, Amodeo S, Facciuto L, Vonahrens D, Sulimani O, et al. Limited upper midline incision for major hepatectomy in adults: safety and feasibility. Turk J Surg 2021; 37 (4): 379-386.

\section{Corresponding Author}

Marcelo Facciuto

E-mail: marcelo.facciuto@mountsinai.org

Received: 14.08 .2021

Accepted: 08.11 .202

Available Online Date: 31.12 .202

() Copyright 2021 by Turkish Surgical Society Available online at www.turkjsurg.com

DOI: $10.47717 /$ turkjsurg.2021.5389

\section{INTRODUCTION}

Conventional open surgery for liver resection is frequently performed to resect primary and secondary liver neoplasm, as well for benign indications. This can be accomplished by various type of incisions including bilateral subcostal incision with or without a vertical extension, a J-shaped incision, and a reverse L-shaped incision with or without a left extension $(1,2)$. Liver lesion size and its anatomical location, as well as its proximity to main blood vessels are major determinants when planning for the extent of the liver resection and the incision type. Conducting liver resection through extended incisions enables obtaining optimal resection margins while maintaining the patient's safety. However, if oncological principles and patient safety can be secured, a shorter incisional length would facilitate post-operative recovery. Since 1990, a growing number of minimal invasive hepatectomy methods have been reported with favorable results. According to the Louisville statement of 2008, a panel of international experts has defined three categories of hepatic minimal invasive surgery: pure laparoscopy, hand-assisted laparoscopy and a hybrid technique (3). The benefits of these minimally invasive procedures, such as shorter hospital stay and less pain, have fueled their rapid adoption (3-7). Nevertheless, there are still technical difficulties with minimally invasive liver resections related to hemorrhage control, liver mobilization, avoidance and management of bile duct injuries and the lack of manual sensation. Furthermore, their technical complexity, substantial learning curve, and expense have restricted their use for selected patients (8). Unlike in non-anatomical and minor liver resections, in major liver resections, defined as the resection of three or more contiguous segments and the resection of posterior superior segments (9), the surgeon still needs to 
make a significant incision for specimen extraction even if the entire procedure was possible with minimal invasive orientation. Therefore, the role of minimally invasive approach in major hepatectomy is not clearly defined, especially if the resection can be accomplished directly through the same minimal incision needed for extracting the specimen and spare all of the above-mentioned burdens of the minimal invasive technique. Yet, the safety and feasibility of this alternative surgical option needs to be studied before it can gain widespread use. Upper midline incision (UMI) has been proven to be feasible, safe and effective in living donor major hepatectomy $(10,11)$. However, there is scant published data in the literature about its role in major hepatectomy for patients having malignant and benign indications. The aim of this study was to report our experience with major hepatectomy through UMI for malignant and benign indications and to analyze its feasibility and safety.

\section{MATERIAL and METHODS}

We performed a retrospective comparative study on a prospectively collected database of 57 consecutive major liver resections performed via an UMI at a single center between March 2010 and December 2019. In addition, data from a control group of 36 patients, who underwent major hepatectomies with a conventional incision (Cl) (defined as bilateral subcostal with midline extension) over the same period, was analyzed in order to compare outcomes with the UMI group. This study was approved by the Institutional Review Board.

We included patients who underwent the following liver resections: right hepatectomy, left hepatectomy, right tri-segmentectomy, and left tri-segmentectomy. The indications were both malignant and benign tumors, regardless of the tumor burden and the involvement of adjacent organs. We excluded patients who underwent resections for the purpose of liver donation.

Surgical indications and plans were determined during a multidisciplinary liver tumor board conference. Pre-operative workup included: laboratory testing, tumor markers, imaging modalities [computed tomography (CT), positron emission CT and magnetic resonance imaging (MRI)] and characterization of the specific tumor (number, location, size and relation to intrahepatic vascular or biliary structures). The patients underwent standard evaluation for major surgery by an anesthesiologist. All patients were informed in detail about the procedure, including the risks and benefits, and written consent was obtained prior to surgery

Blood loss was estimated using the volume of blood aspirated from the abdominal cavity during the procedure. Operative time was defined as the time elapsed from the skin incision until closure. Postoperative hospital stay was defined as the number of days from the operation until the day of discharge, inclusive. Complications were defined as any unexpected event deviating from a normal recovery course. Severity of complications was graded using the Clavien-Dindo scoring system (12)
Tumor burden and resection margins were determined according to the pathological reports from the permanent sections of the extracted specimens. RO was defined as no cancer cells seen microscopically at the resection margin. After discharge, the patients were followed by our multidisciplinary team as every three months for at least two years and every six months thereafter for a patient with malignancy.

\section{Surgical Technique}

The UMI approach for major hepatectomy was performed in the same way as described earlier by our team for living liver donors (10). In brief, after general anesthesia was administered and full muscle relaxation was accomplished, laparotomy was performed using a pre-determined supraumbilical UMI, extending from $1 \mathrm{~cm}$ below the tip of the xiphoid process to $3-4 \mathrm{~cm}$ above the umbilicus (Figure 1). The xiphoid process was excised for optimal suprahepatic caval exposure. The Thompson retractor system was used with pediatric blades to retract the rib cage. The right or left hepatic lobe (depending on the laterality of planned resection) was mobilized by dividing the falciform and coronary ligaments, as well as retroperitoneal and diaphragmatic attachments. The lobe to be resected (right or left) was then mobilized off the inferior vena cava, and the liver was encircled posteriorly with a firm plastic tube in preparation for the hanging maneuver (13-15). The tube held the liver parenchyma up and provided counter-traction for parenchymal transection via the hanging maneuver. This allowed parenchymal transection to be performed at the abdominal midline level, just underneath the abdominal wall midline incision. Vascular inflow obstruction was applied as needed. The ipsilateral hepatic artery and portal vein were divided; if the right lobe was resected

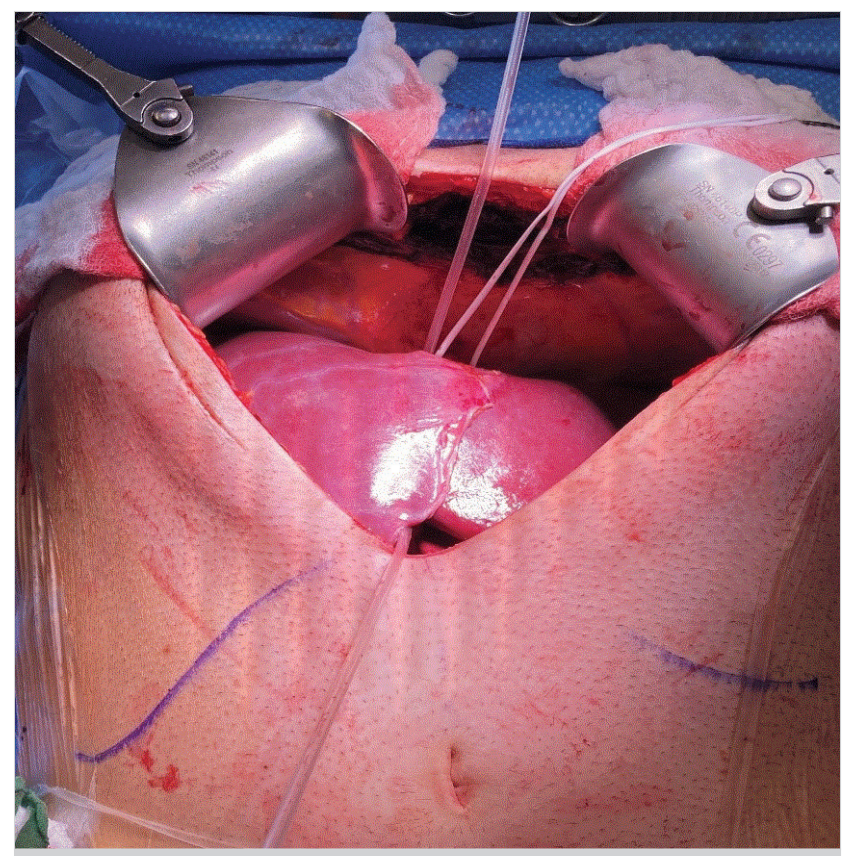

Figure 1. Intraoperative exposure with UMI. 
it was rotated clockwise, anteriorly, and to the contralateral side, where-as the rotation of a resected left lobe was counterclockwise. This was followed by transection of the ipsilateral hepatic vein with Endo GIA ${ }^{\mathrm{TM}}$ staplers (vascular cartridge, Endo GIA ${ }^{\mathrm{TM}}$, Covidien, Norwalk, CT, USA). The parenchymal transection was performed using a Cavitron Ultrasonic Surgical Aspirator (CUSA; Valleylab, Boulder, CO, USA). The specimen was retrieved from the abdominal cavity without difficulty from the UMI. An argon beam coagulator was used for hemostasis. The surgical field was irrigated and checked for bleeding or bile leakage, and residual fluid was removed by suction. An abdominal drain was usually placed over the surgical field. The wounds were then closed in layers. All specimens were sent fresh for pathologic examination to measure surgical margins.

\section{Statistical Analysis}

Descriptive statistics were expressed as mean (SD) or median (range). Chi square test or Fisher's test, where appropriate, was used for univariate comparisons. Patient survival curves were calculated according to the Kaplan-Meier method. Differences were considered significant at $p=0.05$. All statistical analyses were performed using Stata 11 Statistics/Data Analysis (StataCorp, College Station, TX, USA).

\section{RESULTS}

\section{Demographics and Peri-Operative Clinical Data}

From March 2010 to December 2019, this UMI was used in fifty-seven patients for major hepatectomy. Patient characteristics are summarized in Table 1. Median age was 59 years, there were

\section{Table 1. Patient demographics}

\begin{tabular}{|c|c|c|c|}
\hline & UMI & $\mathbf{C l}$ & $\mathbf{p}$ \\
\hline Number, $\mathrm{n}$ & 57 & 36 & \\
\hline Age, years, median, (range) & $59(22-79)$ & $61(33-85)$ & 0.3 \\
\hline Sex, male, \% & $47 \%$ & $72 \%$ & 0.02 \\
\hline $\mathrm{BMl}, \mathrm{kg} / \mathrm{m}^{2}$, median, (range) & $25(15-33)$ & $26(18-35)$ & 0.1 \\
\hline $\begin{array}{l}\text { ASA, n, (\%) } \\
2 \\
3 \\
4\end{array}$ & $\begin{array}{l}12(21 \%) \\
38(68 \%) \\
6(11 \%) \\
\end{array}$ & $\begin{array}{c}7(21 \%) \\
23(70 \%) \\
3(9 \%) \\
\end{array}$ & 1 \\
\hline $\begin{array}{l}\text { Diagnosis, n (\%) } \\
\text { Secondary liver metastasis } \\
\text { HCC } \\
\text { CCA } \\
\text { Adenoma } \\
\text { Hemangioma } \\
\text { Neuroendocrine metastasis } \\
\text { Other }\end{array}$ & $\begin{array}{c}7(12 \%) \\
22(39 \%) \\
15(26 \%) \\
3(5 \%) \\
2(3 \%) \\
1(2 \%) \\
7(12 \%)\end{array}$ & $\begin{array}{c}1(3 \%) \\
14(39 \%) \\
10(28 \%) \\
2(6 \%) \\
2(6 \%) \\
1(3 \%) \\
6(17 \%)\end{array}$ & 0.8 \\
\hline $\begin{array}{l}\text { Chronic liver disease, n (\%) } \\
\text { No } \\
\text { Yes } \\
\text { Etiology, n (\%) } \\
\text { HCV } \\
\text { HBV } \\
\text { NASH } \\
\text { PSC } \\
\text { Other }\end{array}$ & $\begin{array}{c}27(47 \%) \\
30(53 \%) \\
16(28 \%) \\
4(7 \%) \\
3(5 \%) \\
6(11 \%) \\
1(2 \%)\end{array}$ & $\begin{array}{c}20(56 \%) \\
16(44 \%) \\
9(25 \%) \\
3(8 \%) \\
2(6 \%) \\
2(6 \%) \\
0\end{array}$ & 0.9 \\
\hline $\begin{array}{l}\text { Fibrosis, } \mathrm{n}(\%) \\
\text { Underlying liver fibrosis, yes } \\
\text { Stage } 1 \\
\text { Stage } 2 \\
\text { Stage } 3 \\
\text { Stage } 4\end{array}$ & $\begin{array}{c}35(61 \%) \\
10(17 \%) \\
9(16 \%) \\
6(10 \%) \\
10(18 \%)\end{array}$ & $\begin{array}{c}14(39 \%) \\
4(11 \%) \\
10(28 \%) \\
5(14 \%) \\
3(8 \%)\end{array}$ & 0.5 \\
\hline $\begin{array}{l}\text { Child-Pugh-Turcotte Score, median (range) } \\
\text { Child-Pugh-Turcotte Stage, n (\%) } \\
\text { A } \\
\text { B }\end{array}$ & $\begin{array}{l}5(5-8) \\
50(88 \%) \\
7(12 \%)\end{array}$ & $\begin{array}{l}5.5(5-9) \\
28(78 \%) \\
8(22 \%)\end{array}$ & 0.2 \\
\hline Previous upper abdominal surgery, n (\%) & $11(19 \%)$ & $7(19 \%)$ & 0.99 \\
\hline
\end{tabular}


47\% males and 53\% females, with a median body mass index (BMI) of 25 . In $79 \%$ of the patients, the ASA score was above 2, and indication was malignancy in $85 \%$. Fifty-three percent of the patients had known underlying chronic liver disease with hepatitis C virus (HCV) being the major etiology. Liver fibrosis on the pathology specimen was found in $61 \%$ of the patients, almost $30 \%$ of all patients had at least stage 3-4 fibrosis. The majority of the patients were Child-Pugh-Turcotte Class A and 19\% had previous upper abdominal surgery. Liver mobilization, hilar dissection, and parenchymal transection were performed through a limited single upper midline incision. None of the cases required additional subcostal or infra-umbilical extension of the incision for liver resection.

Perioperative characteristics are described in Table 2. Forty-five percent of the patients underwent left hepatectomy, 35\% underwent right hepatectomy and $20 \%$ of the patients underwent trisegmentectomy (mainly right). Vascular inflow occlusion was applied in $28 \%$ of the patients, with a median time of 23 minutes, mostly via Pringle maneuver, with only one patient requiring total vascular isolation (TVI). In addition to major hepatectomy, combined surgery was performed in $42 \%$ of the patients through the UMI: 11 patients had caudate lobectomy, one patient had a Whipple procedure, two patients had right adrenalectomy, six patients had additional liver segmentectomy, and one had resection of a retroperitoneal tumor. Three patients had colectomy; one patient had transverse colectomy from the UMI, one patient had left colectomy from a separate infraumbilical midline incision, and one patient had UMI extended inferiorly for an abdominal perineal resection. Median operative time was 323 minutes, estimated blood loss was 500 $\mathrm{ml}$, and $39 \%$ of the patients required intraoperative blood transfusion. Median post-operative hospital stay was seven days.

\section{Complications}

Surgical complications occurred in 22 patients (39\%) as listed in Table 3. Nine complications (16\%) were Clavien grade II, 5 complications (9\%) Clavien grade III, 3 complications (5\%) were grade IV, and 5 complications (9\%) were grade V. The most common complication was infections $(11 \%, n=6)$. Three patients developed asymptomatic biliary leakage with one patient requiring ERCP and stent placement (IIla), and the other two required re-operation (IIIb). Two patients (4\%) died from liver failure, and three patients (5\%) died from severe sepsis and MOF (V). During the follow up period, six patients (10\%) developed incisional hernia.

\section{Short- and Long-Term Oncological Outcomes}

Median number of lesions in the resected specimens was 1, median size of the biggest lesion was $6 \mathrm{~cm}$. R0 margins were achieved on $89 \%$ of the specimens. Mean follow-up period was 30 months (1-104). Overall survival at year 1, year 3, and year 5 was $82 \%, 77 \%$, and $67 \%$ respectively (Table 4, Figure 2).

Table 2. Perioperative characteristics

\begin{tabular}{|c|c|c|c|}
\hline & UMI & $\mathbf{C l}$ & $\mathbf{p}$ \\
\hline $\begin{array}{l}\text { Type of liver resection, n (\%) } \\
\text { Right hepatectomy } \\
\text { Left hepatectomy } \\
\text { Right trisegmentectomy } \\
\text { Left trisegmentectomy }\end{array}$ & $\begin{array}{c}20(35 \%) \\
26(45 \%) \\
10(18 \%) \\
1(2 \%)\end{array}$ & $\begin{array}{l}15(42 \%) \\
6(17 \%) \\
11(31 \%) \\
4(11 \%)\end{array}$ & 0.01 \\
\hline $\begin{array}{l}\text { Vascular inflow occlusion } \\
\text { Yes, } n(\%) \\
\text { Time, min, median (range) }\end{array}$ & $\begin{array}{c}16(28 \%) \\
23(10-30)\end{array}$ & $\begin{array}{l}11(30 \%) \\
27(9-50)\end{array}$ & $\begin{array}{l}0.8 \\
0.2\end{array}$ \\
\hline $\begin{array}{l}\text { Combined surgery, n (\%) } \\
\text { Types: } \\
\text { Right adrenalectomy } \\
\text { Extra liver segmentectomy } \\
\text { Resection of retroperitoneal tumor } \\
\text { Caudate lobe resection } \\
\text { Colectomy } \\
\text { Whipple procedure } \\
\text { Diaphragmatic resection } \\
\text { IVC resection } \\
\text { Right nephrectomy }\end{array}$ & $\begin{array}{c}24(42 \%) \\
2 \\
6 \\
1 \\
11 \\
3 \\
1 \\
0 \\
0 \\
0\end{array}$ & $\begin{array}{c}19(53 \%) \\
0 \\
4 \\
0 \\
5 \\
0 \\
1 \\
4 \\
4 \\
1\end{array}$ & 0.3 \\
\hline Operative time, min, median (range) & $323(220-692)$ & $384(214-816)$ & 0.06 \\
\hline Estimated blood loss, ml, median (range) & $500(50-4000)$ & $500(100-2200)$ & 0.7 \\
\hline Intraoperative blood transfusions requirement, yes, n (\%) & $21(39 \%)$ & $21(58 \%)$ & 0.04 \\
\hline Post-operative hospital stay, days, median (range) & $7(3-77)$ & $8(4-42)$ & 0.9 \\
\hline
\end{tabular}


Table 3. Post-operative 30-day complications using Clavien classification

\begin{tabular}{|c|c|c|c|}
\hline & UMI & $\mathrm{Cl}$ & $\mathbf{p}$ \\
\hline Complications, yes, n (\%) & $22(39 \%)$ & $14(39 \%)$ & 0.98 \\
\hline $\begin{array}{l}\text { Clavien Classification } \\
\text { II } \\
\text { IIla } \\
\text { IIIb } \\
\text { IVa } \\
\text { IVb } \\
\text { V }\end{array}$ & $\begin{array}{l}9(16 \%) \\
2(4 \%) \\
3(5 \%) \\
1(2 \%) \\
2(4 \%) \\
5(9 \%)\end{array}$ & $\begin{array}{c}9(25 \%) \\
1(3 \%) \\
2(6 \%) \\
1(3 \%) \\
0 \\
1(3 \%)\end{array}$ & 0.6 \\
\hline $\begin{array}{l}\text { Type of complications, n } \\
\text { Fluid Overload } \\
\text { Infectious: fevers, wound, } \\
\text { Pneumonia, } \\
\quad \text { UTI, C. Diff. } \\
\text { Thrombosis: DVT, PE } \\
\text { Portal vein thrombosis } \\
\text { Hemorrhage } \\
\text { Biliary } \\
\text { Colonic complications } \\
\text { Cardiac } \\
\text { Ileus } \\
\text { Kidney failure } \\
\text { Liver failure } \\
\text { Poor nutrition }\end{array}$ & $\begin{array}{l}4 \\
6 \\
1 \\
1 \\
1 \\
3 \\
1 \\
0 \\
1 \\
1 \\
2 \\
1\end{array}$ & $\begin{array}{l}2 \\
5 \\
\\
3 \\
0 \\
0 \\
1 \\
1 \\
1 \\
0 \\
0 \\
0 \\
1\end{array}$ & 0.25 \\
\hline Incisional hernia, yes, n (\%) & $6(10 \%)$ & $5(14 \%)$ & 0.6 \\
\hline
\end{tabular}

Table 4. Pathological findings and post-operative outcomes

\begin{tabular}{|c|c|c|c|}
\hline & UMI & $\mathbf{C l}$ & $\mathrm{p}$ \\
\hline Number of liver lesions, median (range) & $1(1-5)$ & $1(1-5)$ & 0.3 \\
\hline Size biggest liver lesion, cm, median (range) & $6(1.2-19)$ & $8(1.4-28)$ & 0.9 \\
\hline Margins, R0 (\%) & $89 \%$ & $86 \%$ & 0.7 \\
\hline Follow up, months, mean (range) & $30(1-104)$ & $25(1-77)$ & 0.4 \\
\hline $\begin{array}{l}\text { Overall Survival, \% } \\
\text { 1-year } \\
\text { 3-year } \\
\text { 5-year }\end{array}$ & $\begin{array}{l}82 \% \\
77 \% \\
67 \%\end{array}$ & $\begin{array}{l}88 \% \\
63 \% \\
40 \%\end{array}$ & 0.5 \\
\hline
\end{tabular}

\section{Comparison Between Patients with UMI and Cl}

The entire UMI group consisting of 57 patients was further compared with a separate control group of consecutive patients who underwent major hepatectomies with $\mathrm{Cl}$ between March 2010 and December 2019 (Tables 1-4).

There were more males in the $\mathrm{Cl}$ group. There was no statistically significant difference between the groups in terms of age, BMI, ASA score, diagnosis, presence of underlying chronic liver disease, liver fibrosis, Childs-Pugh-Turcotte Class, or history of previous upper abdominal surgery (Table 1). In the UMI group, more patients had right and left hepatectomies, while more trisegmentectomy procedures were performed in the $\mathrm{Cl}$ group. Both groups had similar rates of combined surgeries, and a similar rate and timing for vascular inflow occlusion. In the UMI group, there was a trend towards less operative time $(p=0.06)$ without reaching statistical significance, and the same estimated blood loss. Intraoperative blood transfusions were less needed in the UMI group ( $p=0.04)$ (Table 2). The rate of complications was similar in both groups. Patients in the UMI group tended to have more severe complications than patients in the $\mathrm{Cl}$ group, without reaching statistical significance $(\mathrm{p}=0.6)$ (Table 3). Both groups had similar pathological findings regarding number, size and margins of lesions, with similar survival outcomes (Table 4, Figure 2).

\section{DISCUSSION}

Major hepatectomy being safely performed through UMI in the setting of living liver donation has been previously reported by our group and others $(10,11)$. In the current study, we expand- 


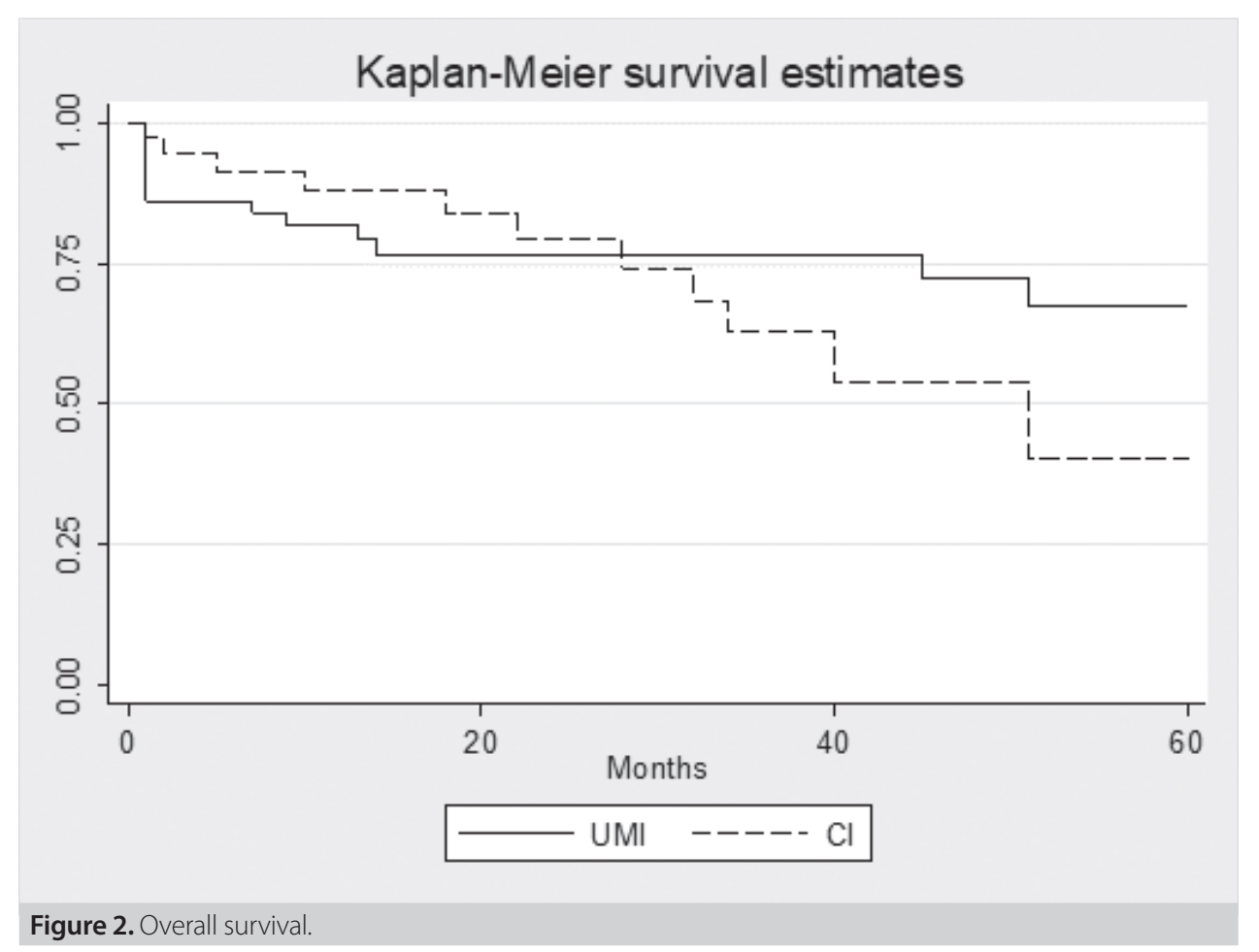

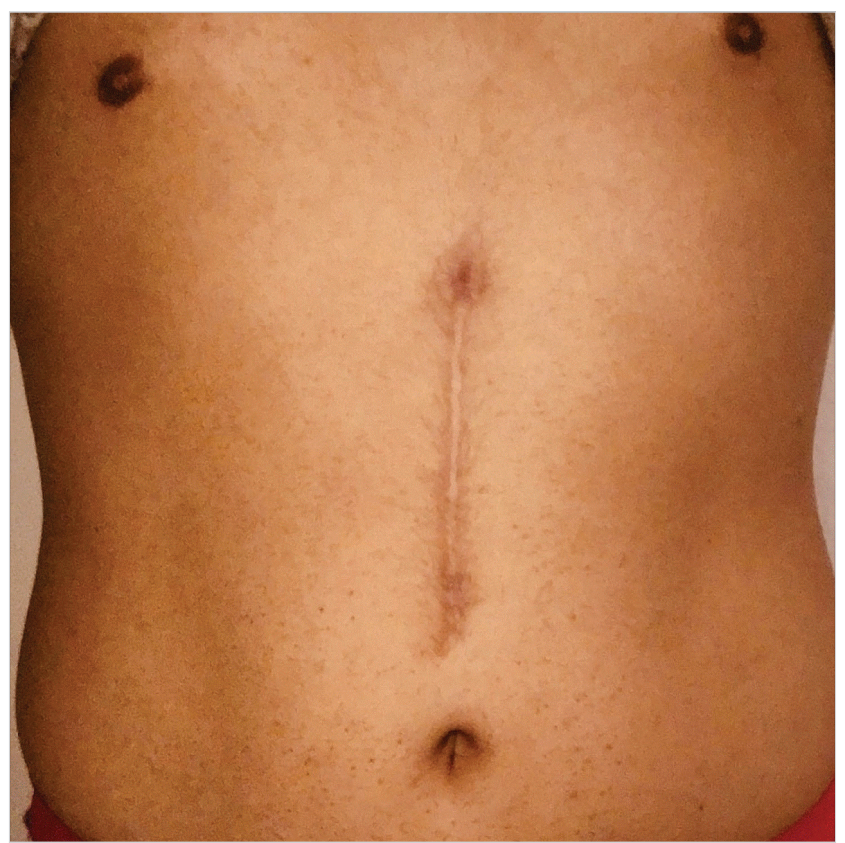

Figure 3. Long-tern cosmetic results with UMI.

ed our experience using an UMI for major hepatectomies in all patients, irrespective of chronic underlying liver disease and the degree of fibrosis, the need of concomitant surgical procedures or receipt of previous upper abdominal surgery. Our results with 57 consecutive patients demonstrate that this approach is both feasible and safe.
In the present study, we compared the patients with UMI to a cohort of patients who had major hepatectomies using Cl. Operative time, the need of vascular inflow occlusion, estimated blood loss, and the need for blood transfusions were comparable with data found in the $\mathrm{Cl}$ patients. Moreover, the length of post-operative hospital stays, complication rate, incisional hernia incidence, resection margins, and survival in the UMI group were similar between the groups.

Unlike $\mathrm{Cl}$, UMI above the umbilicus is one of the most common and familiar incisions in abdominal general surgery, representing an optimal way to begin a liver resection. UMI was performed upon the same patient population as for $\mathrm{Cl}$, with no limitation on patient selection. In particular situations, such as patients with higher BMI, UMI allows for an extension inferiorly and both lateral sides to maximize surgical exposure if necessary. Its cosmetic results are significantly better compared with the standard subcostal incision with positive impact on quality of life, especially in the population of young patients (Figure 3).

Dagher et al. (16) have reported the combined data of 18 international centers performing laparoscopic major hepatectomies. From 1996 to 2014, a total of 5388 laparoscopic liver resections were identified, 1184 of them were major resections. The conversion rate for all major resections was 10\%, mean operative time was $291 \mathrm{~min}$, and mean estimated blood loss was $327 \mathrm{ml}$.

Laparoscopic major hepatectomy can be a formidable task. Limited visualization of the surgical field can result in unexpected and uncontrolled hemorrhage, especially during the expo- 
sure and control of the inferior vena cava and hepatic veins, as well as the parenchymal division. Therefore, a high level of expertise in laparoscopy and good selection of the cases, are required for achieving patient safety and adequate oncological outcome (17).

From a practical aspect, all laparoscopic techniques still ultimately require a large incision for graft extraction, especially when dealing with larger specimens or tumors. When adding the extraction incision length to the sum of the incision's length required for the ports, the comparative benefits of laparoscopic over open surgery using UMI remains a subject for debate and need for future studies.

Kim et al. (18) have reported the use of the UMI technique for liver resections in patients in addition to its use in healthy live donors. They have initially reported results of 308 liver resections through the UMI technique; 160 patients had tumors of $5 \mathrm{~cm}$ in size or less, and 148 were living liver donors. Median length of their incision was $16.4 \mathrm{~cm}$. Their statistical analysis in patients' group did not differentiate between major and minor hepatectomy. They have concluded that UMI can be used safely and effectively in conventional open surgery and should therefore be given priority as the first-line technique in patients with tumors measuring $5 \mathrm{~cm}$ or less. Our study demonstrated that the UMI can be safely incorporated for patients with larger tumor burden (median tumor size $6 \mathrm{~cm}$ ).

The major advantage of the UMI technique is that the incision is confined to the supra-umbilical area, and avoids the additional pain and morbidity that is associated with the bilateral or right subcostal incision and rectus muscle division. Moreover, it provides an adequate surgical field exposure around the right kidney, right adrenal gland, hepato-caval junctions of the hepatic veins, and the inferior vena cava, allowing the performance of combined resections including pancreaticoduodenectomy, when indicated. UMI allows doing the liver mobilization, hilar dissection, and parenchymal transection as does conventional open resection. This longitudinal incision runs along the same plane as the transection line needed for major hepatectomies and also along the same plane at which the force needed for the hanging maneuvers is applied, as described by Belghiti et al. (13) and Kim et al. (14,15). When working from an UMI, the hanging maneuver is critical for optimizing exposure and minimizing bleeding, and decreasing the need for vascular inflow occlusion. The rate for vascular interruption in the UMI group (28\%) was similar with its use in the Cl group (30\%), and in line with its rate in the reported literature for major hepatectomies (24\%) (19). Completion of a liver resection, without interrupting blood flow reduces its detrimental effects such as hepatic ischemia-reperfusion injury, spontaneous spleen rupture, and portal vein thrombosis (20), especially in patients with underlying liver disease.
The retrospective nature of the present study and the relatively small sample size confer limitations on the level of certainty regarding its results. However, we only chose to include patients who underwent major hepatectomies and used strict exclusion criteria. Additionally, this study was nonrandomized, reflected in the asymmetrical size of the two treatment groups

In conclusion, major hepatectomy using a limited length UMI is shown to be both feasible and safe in our series of 57 consecutive patients. It should not be considered as an opposing alternative to laparoscopic techniques or conventional surgical approach, but rather another component of a diverse strategy for the management of major hepatectomies. The choice of a particular surgical approach should depend upon patient individual risk factors and the expertise of the surgical team.

We, therefore, believe that the UMI technique should be considered in the armamentarium of the liver surgeons when planning for major hepatectomy.

Ethics Committee Approval: Thi study approval was obtained from Institutional Board of the Mount Sinai School of Medicine (Project Information: HS\#:20-00917, Date: 31.07.2020)

Peer-review: Externally peer-reviewed.

Author Contributions: Concept - All of authors; Design - All of authors; Supervision - All of authors; Data Collection and/or Processing - All of authors; Analysis and/or Interpretation - All of authors; Literature Search- All of authors; Writing Manuscript - All of authors; Critical Reviews - All of authors.

Conflict of Interest: The authors have no conflicts of interest to declare.

Financial Disclosure: The authors declared that this study has received no financial support.

\section{REFERENCES}

1. Togo S, Nagano Y, Masumoto C, Takakura H, Matsuo K, Takeda K, et al. Outcome of and risk factors for incisional hernia after partial hepatectomy. J Gastrointest Surg 2008; 12(6): 1115-20. [CrossRef]

2. Chang SB, Palavecino M, Wray CJ, Kishi Y, Pisters PWT, Vauthey JN. Modified Makuuchi incision for foregut procedures. Arch Surg 2010; 145(3): 281-4. [CrossRef]

3. Buell JF, Cherqui D, Geller DA, O'Rourke N, lannitti D, Dagher I, et al. The international position on laparoscopic liver surgery: The Louisville statement, 2008. Ann Surg 2009; 250(5): 825-30. [CrossRef]

4. Buell JF, Thomas MT, Rudich S, Marvin M, Nagubandi R, Ravindra KV, et al. Experience with more than 500 minimally invasive hepatic procedures. Ann Surg 2008; 248(3): 475-86. [CrossRef]

5. Kaneko H, Takagi S, Otsuka Y, Tsuchiya M, Tamura A, Katagiri T, et al. Laparoscopic liver resection of hepatocellular carcinoma. Am J Surg 2005; 189(2): 190-4. [CrossRef]

6. Sasaki A, Nitta H, Otsuka K, Takahara T, Nishizuka S, Wakabayashi G. Ten-year experience of totally laparoscopic liver resection in a single institution. Br J Surg 2009; 96(3): 274-9. [CrossRef]

7. Cho JY, Han HS, Yoon YS, Shin SH. Feasibility of laparoscopic liver resection for tumors located in the posterosuperior segments of the liver, with a special reference to overcoming current limitations on tumor location. Surgery 2008; 144(1): 32-8. [CrossRef] 
8. Vibert E, Perniceni T, Levard H, Denet C, Shahri NK, Gayet B. Laparoscopic liver resection. Br J Surg 2006; 93(1):67-72. [CrossRef]

9. Wakabayashi G, Cherqui D, Geller DA, Buell JF, Kaneko H, Han HS, et al. Recommendations for laparoscopic liver resection: a report from the second international consensus conference held in Morioka. Ann Surg 2015; 261(4): 619-29. [CrossRef]

10. Singh MK, Lubezky N, Facciuto M, Contreras-Saldivar A, Wadhera V, Arvelakis $A$, et al. Upper midline incision for living donor right hepatectomy. Clin Transplant 2016; 30(9): 1010-5. [CrossRef]

11. Kim SH, Cho SY, Lee KW, Park Sang-Jae, Han Sung-Sik. Upper midline incision for living donor right hepatectomy. Liver Transpl 2009; 15(2): 193-8. [CrossRef]

12. Dindo D, Demartines $N$, Clavien Pierre-Alain. Classification of surgical complications: a new proposal with evaluation in a cohort of 6336 patients and results of a survey. Ann Surg 2004; 240(2): 205-13. [CrossRef]

13. Belghiti J, Guevara OA, Noun R, Saldinger PF, Kianmanesh R. Liver hanging maneuver: a safe approach to right hepatectomy without liver mobilization. J Am Coll Surg 2001; 193(1): 109-11. [CrossRef]

14. Kim SH, Park Sang-Jae, Lee Soon-ae, Lee WJ, Park Joong-Won, Hong EK, et al. Various liver resections using hanging maneuver by three glisson's pedicles and three hepatic veins. Ann Surg 2007; 245(2): 2015. [CrossRef]
15. Kim SH, Kim YK. Living donor right hepatectomy using the hanging maneuver by Glisson's approach under the upper midline incision. World J Surg 2012; 36(2): 401-6. [CrossRef]

16. Dagher I, Gayet B, Tzanis D, Tranchart H, Fuks D, Soubrane O, et al. International experience for laparoscopic major liver resection. J Hepatobiliary Pancreat Sci 2014; 21(10): 732-6. [CrossRef]

17. Palanisamy S, Sabnis SC, Patel ND, Nalankilli VP, Vijai A, Palanivelu P, et al. Laparoscopic major hepatectomy-technique and outcomes. $J$ Gastrointest Surg 2015; 19: 2215-22. [CrossRef]

18. Kim SH, Kim YK. Upper midline incision for liver resection. HPB (Oxford) 2013; 15(4): 273-8. [CrossRef]

19. Al-Saeedi M, Ghamarnejad O, Khajeh E, Shafiei S, Salehpour R, Golriz $M$, et al. Pringle maneuver in extended liver resection: A propensity score analysis. Sci Rep 2020; 10(1): 8847. [CrossRef]

20. Hoekstra LT, van Trigt JD, Reiniers MJ, Busch OR, Gouma DJ, van Gulik TM. Vascular occlusion or not during liver resection: the continuing story. Dig Surg 2012; 29(1): 35-42. [CrossRef]

\section{ORIJINAL ÇALIŞMA-ÖZET}

Turk J Surg 2021; 37 (4): 379-386

\section{Yetişkinlerde majör hepatektomi için sınırlı üst orta hat insizyonu: Güvenlik ve uygulanabilirlik}

Ahmad Mahamid, Yaniv Fenig, Salvatore Amodeo, Lucas Facciuto, Dagny Vonahrens, Omri Sulimani, Thomas Schiano, Marcelo Facciuto

Mount Sinai Hastanesi, Recanati/Miller Transplantasyon Enstitüsü, New York, Amerika Birleșik Devletleri

\section{ÖZET}

Giriş ve Amaç: Majör hepatektomi için optimal insizyon tartışmalıdır. Bu çalışmada, majör hepatektomi için sınırlı üst orta hat insizyonu (ÜOi) deneyimimizi açıkladık. Çalışmanın amacı, majör hepatektomide ÜOi uygulanabilirliği ve güvenilirliğini analiz etmekti.

Gereç ve Yöntem: ÜOI ile majör hepatektomi yapılan 57 ardışık hasta konvansiyonel insizyon (Ki) ile majör hepatektomi yapılan 36 hastanın dahil olduğu kontrol grubuyla karşılaştırıldı.

Bulgular: Hastaların \%85'inde endikasyon ortanca tümör boyutu $6 \mathrm{~cm}$ olacak şekilde malignite idi. Hastaların \%53'ünde altta yatan kronik böbrek hastalığı mevcuttu ve karaciğer fibrozu hastaların \%61'inde tespit edildi. Hastaların \%19'u daha önce üst batın cerrahisi geçirmişti. Yirmi altı hastaya sol hepatektomi, 20 hastaya sağ hepatektomi ve 11 hastaya trisegmentektomi uygulandı. Hastaların \%42'sinde ek kombine cerrahi girişimler yapıldı. Ortanca operasyon süresi 323 dakika, tahmini kan kaybı $500 \mathrm{ml}$ ve ortanca postoperatif hastanede yatış süresi yedi gündü. Yirmi iki (\%39) hastada cerrahi komplikasyon görüldü. Beş yıllık toplam sağkalım \%67 idi. Ki kontrol grubu ile karşılaştıııldığında, ÜOI yapılan hastalarda operasyon süresi, tahmini kan kaybı, hastanede yatış süresi, komplikasyon oranı ve toplam sağkalım oranlarında istatiksel bir fark yoktu.

Sonuç: Majör hepatektomiler ÜOI ile güvenilir bir şekilde uygulanabilir. Bu yaklaşım, majör hepatektomiler için konvansiyonel ve laparoskopik yaklaşımlara ek olarak akıllıca bir seçenek olarak düşünülmelidir.

Anahtar Kelimeler: Üst orta hat insizyonu, sağ hepatektomi, sol hepatektomi, trisegmentektomi, majör hepatektomi

Doi: $10.47717 /$ turkjsurg.2021.5389 